\title{
A Comparitive Study of Rural Land Property System Reform in Chengdu and Chongqing*
}

\author{
Lei $\mathrm{Fu}$ \\ School of Economics \\ Sichuan University \\ Chengdu, China
}

\author{
Kunzhou Zhai \\ School of Marxism \\ Southwest University of Science and Technology \\ Mianyang, China
}

\begin{abstract}
As the pilot areas of the national comprehensive urban and rural reform, Chengdu and Chongqing first carried out their reform of the rural land property right system and explored its practicality. Both Chengdu and Chongqing initiated the core values of "empowering the peasants" and "land capitalization." Though they shared similarities, differences still exist. The writers in the paper studied the rationale and the practices of the reform in both areas, examined the innate problems and contradictions of the rural land property right system reform in Chengdu and Chongqing, and finally suggest effective strategies for further promoting the reform of the rural land property right from "separation of two rights" to "separating rural land ownership rights, contract rights, and management rights".
\end{abstract}

Keywords-Chengdu-Chongqing experiment; land property reform; comparison

\section{INTRODUCTION}

The problem of "agriculture, rural areas, and rural residents" has long puzzled the economic and social development of China. To resolve the problem of "agriculture, rural areas, and rural residents" largely lies in the fact of how to solve the land ownership system. Since the establishment of the People's Republic of China, the land ownership reform has gone from the private ownership of land to the state ownership of land based on agricultural production cooperatives initiatives, and to the collective ownership of land of people's communes, which finalized the government supported land ownership reform. However, the top-down arrangement of the land reform has not spurred the productive forces, and the agricultural production has been in a stalemate for a time. By the end of 1978, encouraged by the spirit of the Third Plenary Session of the Eleventh Central Committee, eighteen "Red Handprints" which represents the promises of "distributing the fields to the households" in Xiaogang Village of Fengyang of Anhui Province set off the "first shot" in the reform of the rural land property right system in China, hence starting the household contract

*Funding Projects: Supported by the phased objectives of General Project of National Social Science Fund-"Research on the Synergetic Development of New Agriculture, Rural Areas, and Rural Residents with Chinese Characteristics" (15BKS038) and Youth Project of National Social Science Fund-"Research on Mechanism, Path and Policy of Green Governance of Socialist Economy with Chinese Characteristics" (16CKS015) responsibility, even opening a new way for exploring, practicing, summarizing and popularizing the reform of the rural land property right system from the bottom to the top. The practice of subcontracting to households has greatly increased the production incentives of hundreds of millions of rural residents, and has hugely increased their productivity. The double-layer management system based on household contract management has gradually become a basic system in the rural economy of China, and has been implemented steadily for a long time. [1]

However, over time, the institutional effects of the family management responsibility system on agricultural growth have been exhausted. Some flaws of this system are exposed gradually, such as the demand of food caused by the increase of overpopulation, the difficulty of small-scale land decentralized management. The contradiction between the small-scale land fragmentation and the moderate-scale management is becoming more and more prominent. It is urgent to reform the land property right system. [2] Since the $18^{\text {th }}$ National Congress of the Communist Party of China (CPC), the reform of the rural land system has been accelerated to implement collective ownership, stabilize the contractual rights of peasant households, and liberate the right of land management, centering on the subdivision, implementation and protection of the property rights. And it has made a breakthrough in solving the problems of "agriculture, rural areas, and rural residents" in the new period by speeding up the reform of the rural land system from the separation of the two rights to the separation of rural land ownership rights, contract rights, and management rights.

In 2007, the state approved Chengdu and Chongqing as the "pilot area of the national comprehensive urban and rural reform", entrusting Chengdu and Chongqing to carry out the first trial experiences of disintegrating the divided development of the rural and urban areas and focusing on their integration, mutual benefits and growth, which can be popularized and referred to by others. In practice, both focused on the land ownership reform of the rural areas, and aroused the scholastic attention. Scholars, from different perspectives, have done in-depth research and made inspiring findings. Some scholars have thoroughly investigated the concrete land property right reform model in Chengdu-Chongqing area. For example, Luo Biliang (2015) 
analyzed the value of Chongzhou's" innovative agricultural co-operation system" and the three major trading devices [3]. And the research group of Sichuan Academy of Social Sciences (2009) discussed the implication and predicted system innovation, theoretical value and development trend of "two shares and one reform" in Wenjiang [4]. Yang Jirui (2011) and other scholars have made a thorough research and exploration on the theoretical and practical value, existing problems and improvement measures of Chongqing land indicator transaction [5]. Yao Jinwei (2014) abstracted the land co-development mode from the practice of Wubao town in Chongqing, emphasizing the importance of power separation and organization integration on modern land development [6]. Zhou Jian (2011) made a comparative study of three rural land transfer models: Jiaxing model in Zhejiang Province, Wuxi model in Jiangsu Province and Wenjiang model in Chengdu City [7]. Some scholars have carried on systematic research on land property right reform in Chengdu and Chongqing respectively. The National Development Research Institute of Peking University (2010) summed up the practice of Chengdu in land system reform through the specific case system and systematic investigation [8]. Jiang Xiaoping (2011) summed up and refined the reform of rural land property right system in Chengdu by systematically reorganizing the Chengdu experience of "returning rights and empowerment" [9]. Sun Chaoying (2015) comprehensively combed the measures and typical cases of the reform of rural property right system in Chengdu "pilot area" [10]. Yan Jinming (2011) summarized seven models of land management system reform and innovation in urban and rural comprehensive reform of Chengdu pilot area [11]. Zhou Jingxiang (2011) comprehensively summarized the rural land transfer pattern in Chongqing [12]. Mei Zhe (2011) summed up the three highlights of rural land system innovation in Chongqing: the establishment of rural land exchange, land indicator test, the withdrawal of rural land usage right under the reform of household registration system [13]. In the comparative study, a few scholars such as Yang Shunxiang (2010) made a comprehensive comparative analysis of Chengdu and Chongqing from the overall situation of the urban and rural development reform experiment [14], lacking the comparative study on the land property right system reform of Chengdu-Chongqing rural areas. Under this background, this paper summarizes the practical experience in the reform of rural land property right system in Chengdu and Chongqing over the past 10 years, exploring the realistic logic and technical line of the reform. And based on this, this paper compares and analyzes the practice of the reform in the two places in depth, puts forward the question and the suggestions for the following up reform.

\section{REFORM OF LAND PROPERTY RIGHT SYSTEM IN CHENGDU-CHONGQING RURAL AREA: ITS RATIONALE AND METHODOLOGY}

By analyzing the cases, the specific measures and related policies in the reform of rural land property rights system in Chengdu and Chongqing, this paper attempts to find out the rationale and methodology adopted in the reforms in the two places based on the analysis of specific cases

\section{A. Reform in Chengdu}

Since 2004, Chengdu began to co-ordinate urban and rural pilots. In 2007, it was approved as the pilot area for the national comprehensive urban and rural reform. In January 2008, the Chengdu Municipal Government issued the act" Strengthening the Protection of Cultivated Land and Improving the Property Right System of Rural Land and House (tentative)", which sounded the vanguard call of the property right system of rural land and provided government support for the first trial of the property right reform. Since then, under the framework of "stabilizing ownership, perfecting contracting power and releasing management power", the districts and counties of Chengdu have carried out practical exploration. They boldly get rid of the old ideas and bring in the new initiatives. At a time it brings vitality and vigor, like hundred schools of thought contending for supremacy. It has been hailed as the famous "Chengdu model", which is summed up as "returning rights to the peasants and empowering them". "Returning the right" is to return the ownership rights of land, house and other properties to the peasants by laws and regulations, and to restore the property rights of the peasants. "Empowerment" is to allow peasants to have sole right to dispose of their property. Its main content is highly condensed into three concepts, The confirmation of the ownership rights is the basis, and market circulation is the key, and matching laws or regulations is the guarantee. [7] It would be shown as "Fig. $1 " .$. 


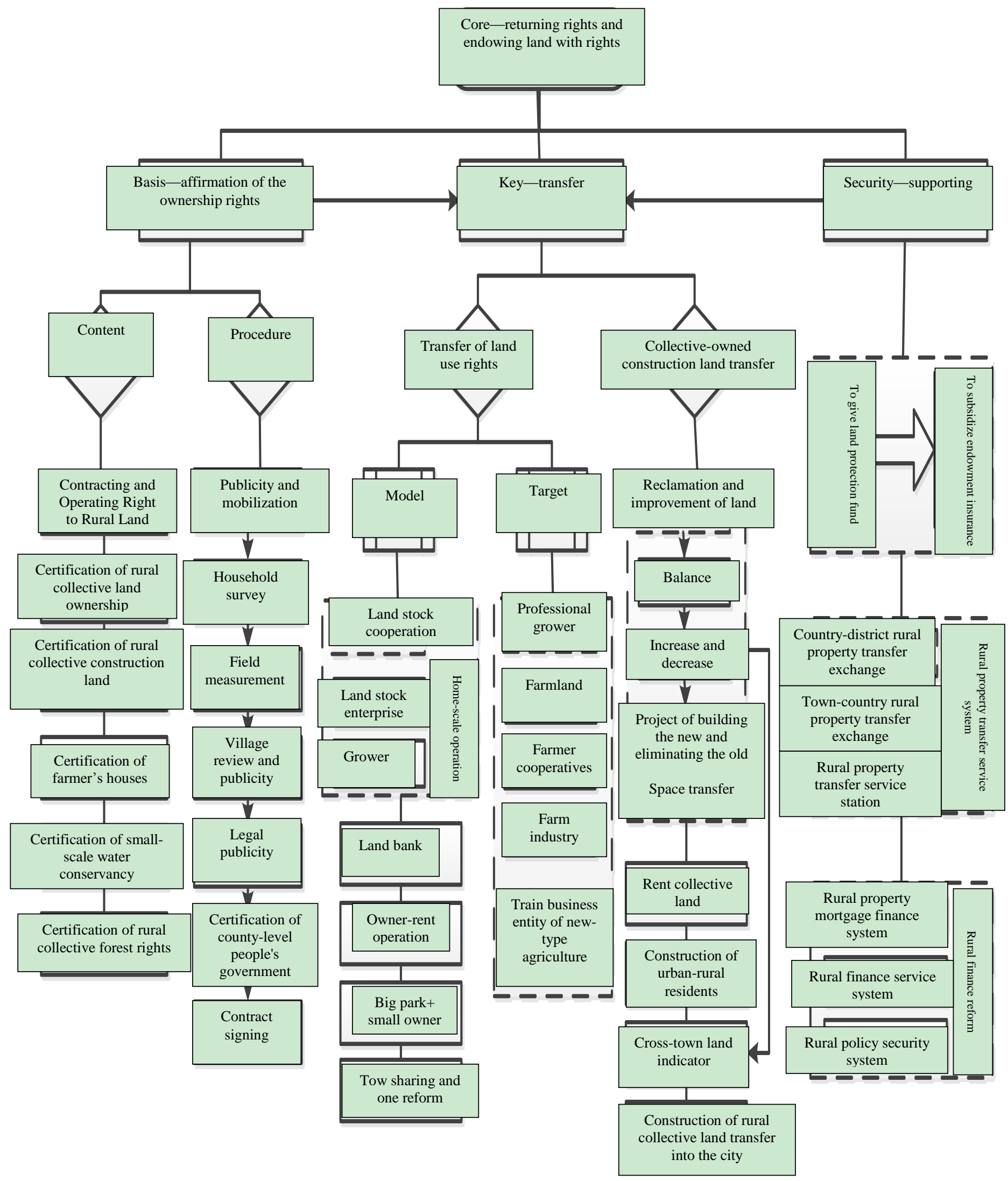

Fig. 1. mapping of rural property system reform of Chengdu. 
1) To fully confirm the rights and issue the certificate: To fully confirm the rights and issue the certificate is to make accurate on-the-spot measurements of every collective land in the city. It should thoroughly clarify the relations between population and land. And each right is truly given to each household. Chengdu has summed up four sentences in the exploratory practice of confirming the right: five consistencies, to confirm as much as possible, standardized procedure, and the satisfactions of masses. "Five consistencies" should achieve one-to-one correspondence of land, accounts, certificates, contracts and farming funds. And the accounts (certificates) should be in real terms. "It should confirm as much as possible". In addition to illegal occupation of land and construction, rural collective land and the construction on the collective land should be confirmed, registered, and issued certificates to ensure that no "dead corner". "Standardized procedure" requires strict implementation of seven links of the work procedures such as the organization mobilization, household investigation, on-the-spot survey, village review and public notice, legal public notice, certification, and contract signing. And key steps cannot be saved. It can't lack the basic links. "Mass satisfaction" requires the establishment of a third-party investigation and evaluation mechanism. And then, we could have satisfaction assessment. And then, it should establish mediation mechanism to resolve contradictions. Thus, the masses can be satisfied. In 2012, 256 townships (street offices), 4267 villages (communities), more than 30,000 villager groups and more than 1.72 million peasant households had completed the work to register and issue certificates. [15] In 2016, on the basis of the "six rights" in rural areas, the "four new rights" were issued, including the ownership of agricultural production facilities, the management of rural land, the management of rural aquaculture water and the ownership of small water conservancy facilities, with a certification rate of $99.5 \%$. Through confirming the right, the "family situation" was found out comprehensively and truthfully, which laid an important foundation for further promoting the rural land transfer. [16]

2) To speed up rural land transfer: Relying on the achievement of confirming the right, Chengdu gets the opportunities. Under the unified planning of urban and rural development, and the guidance of the concept of "whole Chengdu", it actively promotes the orderly transfer of contractual management right and the usage right of collective construction land according to the regional characteristics of "three big circles". In the transfer of contractual management rights of rural land, it mainly took the land joint-stock company, cooperatives, big growers, land bank, and so on. "Cooperatives + Professional Managers + Social Services" emerged in Chongzhou. The model of "two shares one reform" + "two abandonment and three guarantees" emerged in Wenjiang. The model of "big park + small owner" emerged in Yongan. The model of "stock field system + collective agricultural enterprise" emerged in Tangying. All of these models have effectively cultivated new agricultural management subjects such as family farms, large professional households, farmers' cooperatives and agricultural enterprises. And they have promoted agricultural scale management and accelerated the development process of modern agriculture. As of 2014, the area of agricultural land transfer is 4,391,000 mu, accounting for $32 \%$ of the total area of agricultural land. The cultivated land transfers are 3.542 million mu. It accounts for $55.7 \%$ of the total cultivated land. There are more than 40,000 owners who have more than $20 \mathrm{mu}$ of transferable land, 476 municipal-level leading agricultural enterprises, 6190 farmers' cooperatives, 752 land-share cooperatives, 2143 family farms, and 52884 professional households. The new type of agricultural main body drives the production and operation of more than two million local farmers. [17] In the transfer of the usage right of collective construction land, Chengdu has carried out a lot of beneficial exploration and practice around the collective construction land and the state-owned construction land "the same land and the same right". Zhou Qiren (2010), who has long been concerned about the reform of rural property rights in Chengdu, had made a summary. The farmland and village renovation provides balance and hook-up indicators for urban land use. From the industrial parks and operating houses built on the collective land, to the urban and rural residents after the earthquake, inter-county exchange land indicators, and finally rural collective construction land, Chengdu would use different paths to explore the rural area and farmers to share the real possibility of increasing land income in the rapid development of urbanization. [6]

3) To do a good job of supporting protection: In order to optimize the allocation of resources, and promote the standardized operation of land transfer, Chengdu set up the rural property exchange in October 2008, established the first comprehensive trading platform of rural property rights in China, and then established the sub-offices of 15 districts (cities) and counties and 257 rural property rights exchange service stations. It has formed the three-level rural property rights transfer service system of cities, counties and townships. And then, it has successively realized 28072 transactions of land management rights. The transaction amount reached 21.35 billion yuan. Relying on the platform of property right transaction, it effectively solves the loss of peasants' rights and interests caused by information asymmetry, and effectively promote the practical innovation of rural property right transfer mode. In the course of the reform of rural property right system, Chengdu has always upheld the protection of cultivated land as an important principle in its reform. It took the lead in establishing the system of cultivated land protection fund. The government at the municipal, district (city) and county levels has drawn more than 2 billion yuan from the paid use fee and the fee of land transfer or collective construction land. The cultivated 
land that has been certified is paid according to the standard of 400 yuan $/ \mathrm{mu} / \mathrm{year}$ for basic farmland and 300 yuan/mu/year for general farmland. Ten percent of the money is used to guarantee the transfer of cultivated land and agricultural insurance subsidies. And the rest is used to subsidize the endowment insurance of peasant households. In turn, the farming fund system promoted the smooth implementation of the land certification. And it formed a "backward force" mechanism for the reform. At the same time, it carried out rural financial reform. And introducing more credit funds and social funds into rural areas are also an important safeguard measure to promote the reform of property rights. Chengdu insists on the trial first. And it pushes forward the financing of rural property right mortgage. The amount of financing of land contractual management right and land management right mortgage reaches 110 million yuan. And the amount of other kinds of rural property right mortgage financing exceeds 10 billion yuan. Through the development of small credit agricultural loans, and the establishment of rural banks, it has explored the financial cooperation based on farmers' professional cooperatives, Internet + rural finance, rural inclusive financial services and so on. And it constantly improves the financial service system. Eighteen policy-oriented agricultural insurance policies were introduced. And a catastrophe risk reserve of 100 million yuan was extracted. Thus, it effectively improves the ability of agriculture to resist risks. With the advancement of rural financial reform, more farmers enjoy the benefits. [7]
Through the practice of the reform of the property right system, Chengdu has effectively promoted the construction of Happy New Village and improved the production and living conditions of the peasants. It accelerates the process of agricultural industrialization and creates the necessary conditions for the development of modern agriculture and the establishment of new agricultural management system. By 2016, the per capita disposable income of rural residents was 18,605 yuan, and the ratio of urban income to rural income dropped to 1.93: 1. At the same time, centering on the requirements of "implementing collective ownership, stabilizing peasant households' contracting right and releasing the land management right", the author takes the lead in carrying out the exploration and practice of "separating rural land ownership rights, contract rights, and management rights" and the issuance of land authorization in the whole country. And the author sums up a series of valuable experiences which can be popularized and replicated to crack the dual structure and reconstruct the scientific urban-rural relationship. It will give full play to the trial and demonstration.

\section{B. Reform in Chongqing}

Compared with Chengdu, Chongqing's reform of farmland property right system has no systematic trajectory to follow. On the basis of reforming measures in Chongqing, this paper holds that the core of Chongqing's reforming is the capitalization of agricultural land, which drives the flow of urban and rural elements. In the process of capitalizing reforming, "four mechanisms" have been formed; namely, guarantee mechanism, circulation mechanism, financing mechanism and incentive mechanism. It is shown as "Fig. 2".

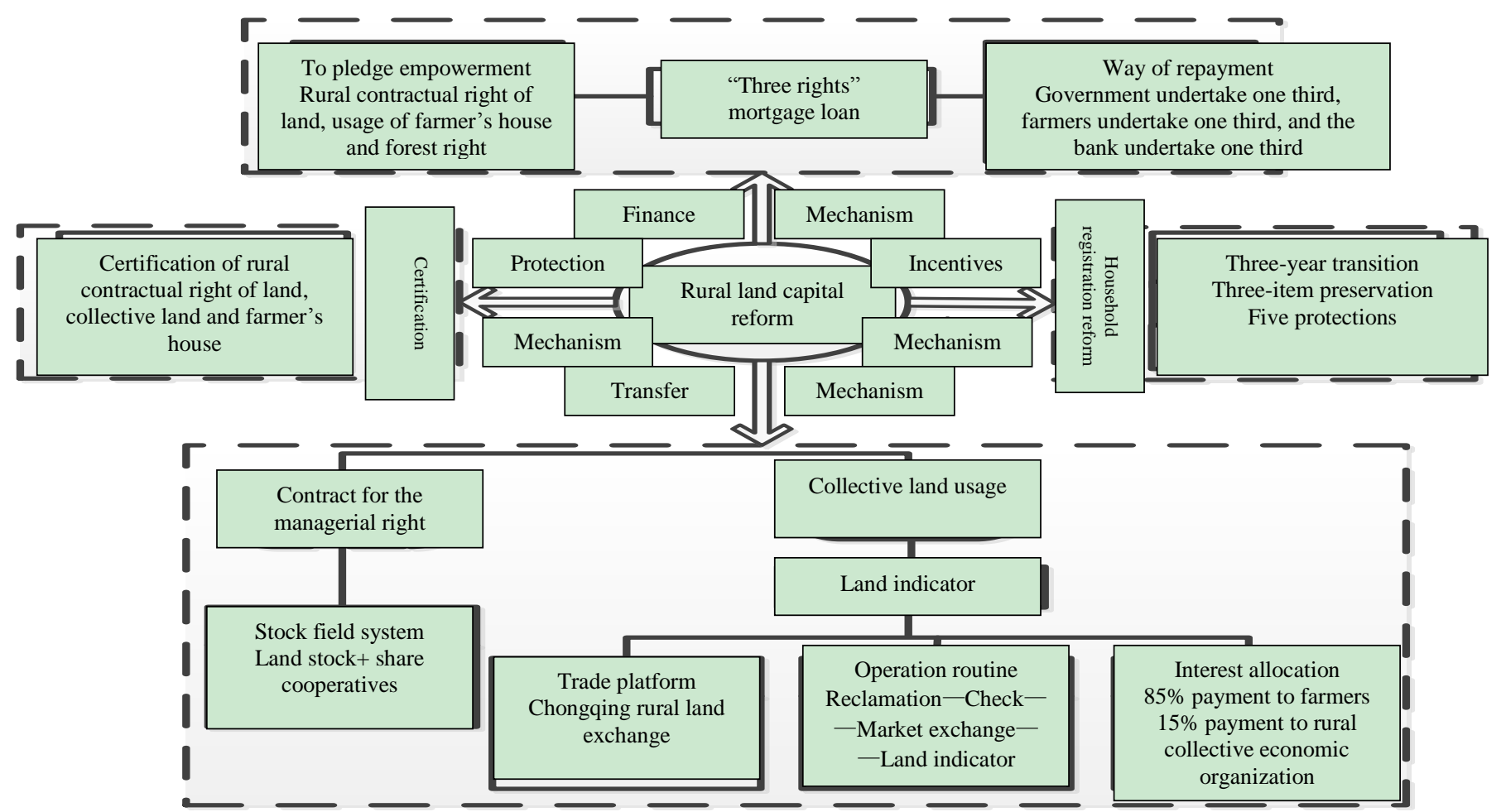

Fig. 2. Logic road map of Chongqing farmland property right system reform. 
1) The safeguard mechanism: Certification is an important guarantee for land transfer. In the course of the reform of rural land system, Chongqing gradually realized the importance of the confirmation, and started the certification in 2010. In 2012, Chongqing basically completed the certification of the contractual management right of rural land, collective land ownership, homestead use right and farmhouse ownership, which laid the foundation for promoting the innovation of land circulation practice.

2) The transferring mechanism: In the transfer of contractual management rights, the most influential practice in Chongqing is the "stock field system". In 2006, there is a large number of abandoned farmland. Under the collective leadership of Qilin Village in Changshou District of Chongqing, farmers put forward the idea of developing citrus production. And they had registered the first farmland company in China. Stock farmers can not only get dividends, but also participate in the specific operation and management of the company, and earn wages. The overall income of farmers has been greatly improved. In the second year, Chongqing Municipal Government introduced the experience of Qilin Village into the reform documents. And then, it had acquired "legal status" in Chongqing. The "stock field system" of Qilin Village has aroused widespread concern of all walks of life for a while. However, after onthe-spot investigation by the Office of the Central Rural Work Leadership Group, hidden worries were raised. They urgently called for a halt to the "stock field system" and advocated the development of professional cooperatives. Although the practice of "stock farmland system" ended without a sickness, it opened up the forerunner to explore the transferring mode of contractual management right in Chongqing in the new period. Since then, various transferring modes, such as land trusteeship, joint development of specialized cooperatives and so on, have become popular, which have effectively driven the circulation of land all over Chongqing and promoted the large-scale operation of agriculture. According to the situation, the land circulation rate has reached $41 \%$. And the concentration of moderate scale operation has increased to $34 \%$. A total of 13,500 family farms and 130,000 growers were developed. There are 25,000 farmers' cooperatives, of which 3150 are new-type rural joint-stock cooperatives. And the participation rate of farmers has increased to $54 \%$. There were 3,362 leading agricultural enterprises and 68,000 rural brokers. [18]

In the transfer of collective land use right, as a "benchmark" in the reform of rural land property right system in Chongqing, it has attracted a lot of attention and local "favor". And it can provide an excellent way of thinking and operation for resolving the contradiction between the rapid urbanization development and the tight construction land index. "Land indicator" refers to the rural collective construction land, such as the land for residential land and its ancillary facilities, the land for township enterprises, the land for rural public facilities and the land for rural commonweal undertakings, which has been reclaimed and relocated to occupy the land. And they have been strictly checked and accepted by the land management department. After reclamation and resettlement, they would increase or decrease the urban and rural construction land indicator. [3] The smooth operation of the land indicator system cannot be separated from the trading platform. That is the Chongqing Rural Land Exchange. It was founded in December 2008. And it is the first rural land exchange in the country, effectively promoting the realization of rural land assets. The main body of land indicator allocation is "agriculture, rural areas, and rural residents". After deducting the cost of farmland reclamation, $85 \%$ of the remaining net income is paid to farmers, and $15 \%$ is paid to rural collective economic organizations. The farmers can enjoy the value-added benefits of land. Essentially, "Land indicator" is a kind of "increase or decrease" of urban and rural construction land within a wider geographical scope. It releases the income of land rent, alleviates the contradiction between strict protection of cultivated land and rigid demand of construction land in the process of urbanization, realizes the fund back-feeding to the rural development in the outer suburbs, and effectively promotes the coordinated development of urban and rural areas. Up to May 2016, Chongqing Municipality held a total of 47 trade fairs, accumulating 177,000 mu of land indicator. The transaction amount reached 35.34 billion yuan. And the average price of per mu was nearly 200,000 yuan. The price control in the development of cities and towns, farmers' rights and interests have been guaranteed in reasonable range. And it effectively opened the way to realize the rural land property rights. [19]

3) The financing mechanism: Through the establishment of three-right mortgage financing system (the contractual management right of rural land, the use right of agricultural house and the forest right), and the stock assets of rural areas have been enlivened. The financing problems of rural economic development and increasing peasants' income have been effectively solved. And a complete supporting guarantee policy has been established. Aiming at the peasants who have lost their land due to the disposal of mortgaged property, the paper also constructs the mortgage payment mechanism of "Three-three Law". That is, the government uses the land mortgage guarantee fund or the land indicator income to feed back. And it would undertake one-third of the responsibility. The land-use enterprise shall bear a third of the responsibility. Farmers who have lost land shall bear the remaining one-third of the responsibility. By the end of 2015, Chongqing had achieved 80 billion yuan in rural equity mortgage financing and 16.69 billion yuan in mortgage financing for agricultural housing. At the same time, combining with the land indicator transactions, Chongqing is also exploring the way of financing such as land indicator mortgage. It has leveraged huge amounts of funds into rural development. And land capitalization is increasingly evident.

4) The incentive mechanism: After land transfer, the future of residents is a major issue. It is related to the 
immediate interests of the peasants. Also, it is a key issue which relates to the livelihood of the people and local stability. At the same time, it is also related to the smooth advancement of land transfer. In this regard, Chongqing has designed a complete set of policy implementation mechanism to encourage farmers to make the development in cities. And it could be summed up as a three-year transition, three reservations and five inclusions. The term "three-year transition" refers to the right to use and benefit of the homestead and contracted land that is allowed to be transferred to peasants for a maximum period of three years. For "three reservations", rural residents can continue to retain the right to use forestland after registered permanent residence transfer. Second is to retain the policy of family planning. Third, all subsidies in rural areas should be retained. "Five inclusion" means that rural residents can enjoy the employment, social security, housing, education, medical policies of cities and towns after the transfer of households. "Five items of security" will be put in place in one step after the transfer of households to cities and towns. And they will enjoy the same treatment as the residents of cities and towns. Practice has proved that it would protect the farmers' legitimate property rights according to the law, and promote the equalization of public services. This would effectively stimulate the enthusiasm of rural residents to make the transfer. By June 2016, Chongqing had a total of 4.366 million households and 1.125 million households. The urbanization rate of registered urban population increased from $29.2 \%$ to $47.6 \%$, and the urbanization rate of permanent resident population rose from $51.6 \%$ to $60.9 \%$. [20]

The reform of farmland property right system which takes the capitalization of farmland as the core in Chongqing has released tremendous vigor of development and provided an operable model for solving the problem of "agriculture, rural areas, and rural residents" in the new period. In recent years, the Chongqing agricultural development space has been effectively expanded. The agricultural standardization, the intensification, and the organization level have been greatly enhanced. In 2016, the per capita disposable income of rural permanent residents reached 11549 yuan. The income gap between urban and rural residents narrowed to 2.56: 1. And the Engel coefficient of rural residents dropped to $38.7 \%$. The construction of beautiful villages has been steadily advanced. The appearance of the villages is greatly improved. The convenience of production and life and the happiness index of the peasants are greatly improved.

\section{THE REFORM OF LAND PROPERTY RIGHT SYSTEM IN CHENGDU AND CHONGQING: SIMILARITIES AND DIFFERENCES}

The reform of land property rights system in rural areas of Chengdu and Chongqing has been carried forward in an all-round way under the background of the pilot areas of comprehensive reform of urban and rural areas. The policy awarded to the pilot area has evaded many legal risks and the red line of the current policy. And it has effectively aroused the enthusiasm of the local government and peasants to participate in the reform, showing the following common characteristics:

\section{A. The Strong Dominance of Government will Be Paralleled with the Spontaneous Reform of Peasants}

As the promoter of reform, the government plays an important role in formulating policies, setting up platforms and coordinating the interests of all parties. Powerful leadership is indispensable in the early stages of reform. For example, the certification is gradually completed by the efforts of the government, which has laid an important foundation for reform and cleared many obstacles. However, breaking through policy restrictions and promoting the flow of urban and rural land elements is equivalent to arousing sleepy capital. Restricted by the performance evaluation mechanism and the urgent need to promote urban development and construction, it is very difficult for the government to confine itself to the role of "referee". Especially in the collective construction land transfer, the initiative of the government is obvious. From the policy of "increasing or subtracting linkage" in county territory to the transaction of land indicator flowing across regions, the contradiction between the tightened urban construction land and the central government's policy of strictly observing the cultivated land red line has been solved to a great extent. And an important breakthrough has been found for speeding up the process of urbanization. Today, the land finance gradually goes towards the end. And the land indicator can be said to be "spark", which has reignited the financial hope for the government. Comparatively speaking, in the contracted land transfer, it is manifested as the spontaneous behavior of the village collective or the villagers. From Chongzhou, Chengdu, "Cooperative + Professional Manager + Social Service", Yongan "Big Park + Small Owner", "Stock field System + Collective Agricultural Enterprise" in Tang Ying to the reform of "Land Stock + Company" in Qilin Village of Chongqing, they are the practice and exploration of the local peasants or leaders. They are based on the reality within the framework of the current legal system and policy that inherits and develops the spirit of "Xiaogang Village" in the new period. And it frees the restraint of the development of "small peasant economy", promotes the process of agricultural modernization, forms a lot of beneficial experience, and provides a "model" for the reform. The reform of the government and the peasants in their respective fields goes hand in hand. Once encountered a conflict of interest, this harmony will be hard to sustain.

\section{B. To Adhere to People's Livelihood-oriented and Benefit People}

In the course of the reform, the government always insisted on improving the people's livelihood and promoting the peasants' income to become rich as the starting point and the foothold, which made the peasants' sense greatly enhanced. First of all, after the right is confirmed, Chengdu government distributes farming fund for farmers according to their land area. It is used to supplement endowment insurance and provides "double protection" for farmers. Secondly, whether the income of land ticket transaction, 
contracted land transfer, or collective land rental income, they are used for "agriculture, rural areas, and rural residents". Through the land transfer, it would increase the income of the peasants' property and wages. The income level has been actually increased. After the replanting of the homestead, many peasants live in buildings. The water and electric networks have been connected. The community services have been promoted. And beautiful new villages have been built. The peasants' production and life styles have undergone tremendous changes. In addition, Chengdu annually allocates more than 400,000 village-level public service funds from the budget to each village. It is directly beneficial to the villagers for the construction of villages and the supply of public services. Thirdly, in the reform of household registration system, it is emphasized that peasants should not withdraw from the contracted land when they settle in the city. Thus, it would ensure the peasants' rights and interests.

\section{Element Marketization Is an Important Means of Reform}

In the process of China's reform and opening-up, the rapid development of land, capital, and labor and other factor markets has released huge dividends, which has promoted the sustained and high-speed economic growth. However, for the consideration of protecting cultivated land and guaranteeing food security, the country blocked the natural flow of urban and rural elements through the arrangement of system, and hid the capital rights and interests of rural land artificially. It has formed the phenomenon that the rights of urban and rural construction land are not equal. The reform of land property right system in Chengdu and Chongqing takes the land factor market as the breakthrough point, and takes the urban and rural land "same price and same right" as the guidance. It gradually opens the rural factor market, and has greatly inspired the rural market development vigor. The gradual opening of the rural land factor market has promoted the land contractual management right to take part in the stock market, the development of stock cooperatives, the establishment of land banks, and the practical exploration on "increasing or decreasing" urban and rural construction land. It has also accelerated the flow of rural labor factor and the transfer of surplus labor force while increasing peasants' property income. The rural financial system, such as "threeright mortgage loan", has come into being to realize the return of funds from the city to the countryside. And it has provided important financial support for the development of the countryside and agriculture.

\section{To Pay Attention to the Coordination and Follow-up of Supporting Safeguards}

Land is the most important safeguard for the peasants, and it is the last straw to save their lives. To the peasants who depend on the land for their livelihood, and to the peasants who have failed in the development of migrant workers in cities, they can still return to the land to live in subsistence and clothing. This explains why many peasants would rather abandon the land than transfer it or withdraw from it. At the same time, this is also the difficulty of the reform of rural land property right system. In order to relieve the worries of peasants and move away from the blocking stones of land transfer, Chengdu and Chongqing should first comprehensively promote the issuance of confirmation. And then, they would ensure the peasants' right of contracted land by law. And the peasants can transfer the land safely out of Chengdu and Chongqing. Secondly, the reform of household registration system should be promoted to provide the farmers with perfect medical care, education, social security, employment, housing and other guarantees. Then, it would achieve the equalization of public services. The farmers can settle down and develop in the city. The reform of rural land property right system is a systematic project, which relates to the overall situation of urban and rural development. It is necessary to treat every link of the reform with the view of development and the thinking of connection. And it should ensure that the supporting measures are in place. Then, it would achieve the actual effect of the reform.

In the concrete practice of the reform of the farmland property right system, the reform of Chengdu and Chongqing is different because of the different factors such as the objective condition, the development idea and so on. It is shown in "Table I".

TABLE I. CONTRAST OF THE DIFFERENCES IN THE REFORM OF FARMLAND PROPERTY RiGHTS IN CHENGDU AND CHONGQING

\begin{tabular}{|c|c|c|}
\hline & Chengdu & Chongqing \\
\hline 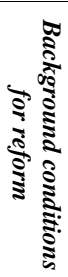 & $\begin{array}{l}\text { Chengdu has a flat terrain, most of which is in the hinterland of plain. } \\
\text { And the proportion of available area can reach } 94.2 \% \text {. The social } \\
\text { economy develops in a "circle". The central urban area develops } \\
\text { rapidly. And the economy is strong. The urbanization rate is relatively } \\
\text { high. The central urban area is obvious to the driving function of } \\
\text { peripheral radiation. And it is the big suburb of typical metropolis belt. } \\
\text { In } 2007 \text {, Chengdu realized } 332.44 \text { billion yuan of GDP and } 26527 \\
\text { yuan of GDP per capita. }\end{array}$ & $\begin{array}{l}\text { Chongqing is surrounded by mountains on three sides, most of } \\
\text { which are hills and mountains. There are obvious differences in } \\
\text { regional development. Big cities, big countryside, big mountainous } \\
\text { area and big reservoir area coexist, belonging to the typical "small } \\
\text { horse carriage", which is the epitome of the dual economic structure } \\
\text { of urban and rural areas in China. In } 2007 \text {, Chongqing achieved } \\
\text { GDP of } 509.666 \text { billion yuan, per capita GDP of } 18.025 \text { yuan. }\end{array}$ \\
\hline 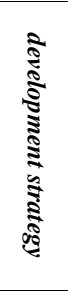 & $\begin{array}{l}\text { Chengdu put forward the concept of "whole Chengdu". According to } \\
\text { "198" ecological and comprehensive function area planning of modern } \\
\text { service industry, it makes scientific layout, and promotes the overall } \\
\text { coordinated development of the city. }\end{array}$ & $\begin{array}{l}\text { Chongqing has constructed a regional development pattern of "one } \\
\text { circle and two wings", with the economic circle centered on the } \\
\text { main urban area as its core, which has more than half of the } \\
\text { population and a relatively high level of economic development. } \\
\text { This has led to the development of Chongqing's northeast region, } \\
\text { with Wanzhou as its center and the Three Gorges Reservoir Area as } \\
\text { its main body, and the poverty-stricken mountainous areas in } \\
\text { southeast Chongqing with Qianjiang as its center, which has } \\
\text { inhabited by ethnic minorities. }\end{array}$ \\
\hline
\end{tabular}




\begin{tabular}{|c|c|c|}
\hline & Chengdu & Chongqing \\
\hline 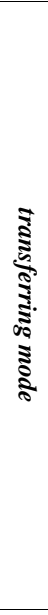 & $\begin{array}{l}\text { Chengdu agricultural land transfer mainly includes the lease, equity, } \\
\text { and subcontract. The land transfer area accounts for } 32 \% \text { of the total } \\
\text { area. The land transfer experiment embodies the pioneering spirit of } \\
\text { the peasants. We have gradually formed a joint-venture system of } \\
\text { "land-share cooperatives + agricultural professional managers + social } \\
\text { services", "total support for production, service contracting", } \\
\text { "corporate trusteeship, specialized operation", "leading enterprises + } \\
\text { specialized organizations + family appropriate scale", "park (base) + } \\
\text { specialized organizations + family appropriate scale" and other } \\
\text { business models. And it should focus on promotion. During the } \\
\text { transfer of collective construction land, Chengdu has made even great } \\
\text { progress. From the leasing of collective construction land, the joint } \\
\text { construction of urban and rural residents, the increase and decrease of } \\
\text { cross-county and municipal "linkage" to the direct entry of collective } \\
\text { construction land into the market, a set of "combinatorial boxing" has } \\
\text { been played out. Although it has broken through the existing policies } \\
\text { and faced many legal risks, it has actually played the role of the first } \\
\text { trial in reforming the experimental area and provided the practical } \\
\text { basis for the future policy of China. }\end{array}$ & $\begin{array}{l}\text { With the complex terrain, various localities have carried out various } \\
\text { forms of farmland transfer, such as land equity, company } \\
\text { contracting, cooperative driving, enterprise leasing, paid } \\
\text { subcontracting, land transfer, land exchange, and so on. The } \\
\text { proportion has reached } 40 \% \text {. Most of the farmland transfer has been } \\
\text { carried out under the impetus of the government. And it has been } \\
\text { learned from the existing institutional framework, and has not } \\
\text { formed innovative institutional achievements. The "Qilin model" has } \\
\text { aroused great concern. Also, it died halfway because of huge risks. } \\
\text { In the practice of collective construction circulation, Chongqing was } \\
\text { flourishing because of the "land indicator". It constantly made the } \\
\text { summary and improvement in practice. And it has been promoted in } \\
\text { many places. Because of the tremendous benefits hidden behind the } \\
\text { deal, the government held the tree firmly. And the results of } \\
\text { explorations spontaneously made by the peasant masses were hard to } \\
\text { show. }\end{array}$ \\
\hline 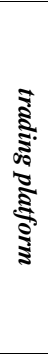 & $\begin{array}{l}\text { The Chengdu Rural Property Exchange is the first comprehensive rural } \\
\text { property rights trading market in China. It takes the operation } \\
\text { according to the modern enterprise management model. It mainly deals } \\
\text { with rural land contractual management rights, forest rights, rural } \\
\text { house ownership, collective construction land use rights, rural } \\
\text { collective economic organizations, agricultural intellectual property } \\
\text { rights and other rural property rights, the transaction of the index of the } \\
\text { collectively-built land and the index of the balance of the supplement } \\
\text { and supplement made by the comprehensive renovation of the rural } \\
\text { land, the disposal of assets, etc. For specific transactions, it should } \\
\text { establish municipal level of the system norms. }\end{array}$ & $\begin{array}{l}\text { Chongqing Land Exchange is subordinate to Chongqing Municipal } \\
\text { Land Administration Bureau. It is guided by the administrative } \\
\text { departments of Chongqing Municipality, such as land, agriculture } \\
\text { and forestry. At the beginning of its establishment, Chongqing Land } \\
\text { Exchange is mainly engaged in the transaction of land indicator. } \\
\text { And then, it develops into a service platform for the transfer of rural } \\
\text { land contractual management rights. For the transaction of matters, } \\
\text { procedures and so on, it lacks municipal level of institutional norms. }\end{array}$ \\
\hline 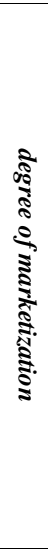 & $\begin{array}{l}\text { At the beginning of the reform, Chengdu fully completed the } \\
\text { certification with the strong guidance of the government. From the } \\
\text { system, it protects the land property rights of farmers. Also, it has laid } \\
\text { an important foundation for the development of the rural land market, } \\
\text { capital investment and the establishment of the financing system. In } \\
\text { the concrete practice of circulation, it fully mobilized the enthusiasm } \\
\text { of farmers. "Chongzhou Model", "Wenjiang Model" and many other } \\
\text { innovative models are driven by the village collectives, leaders and } \\
\text { others. With the role of demonstration, it would attract more farmers to } \\
\text { join in. And then, it would gradually have the development. And in the } \\
\text { distribution of income, the government effectively achieved to put } \\
\text { down the right and make profit. And it insisted that all the } \\
\text { development results returned to the "agriculture, rural areas, and rural } \\
\text { residents". The government has really played the role of policy } \\
\text { designer, operation supervisor and safeguard of rights and interests. } \\
\text { And it has accelerated the marketization process of property right } \\
\text { reform. }\end{array}$ & $\begin{array}{l}\text { In the initial stage of the reform of the property right system in } \\
\text { Chongqing, there was no systematic planning. And the certification } \\
\text { was carried out under the unified promotion of the whole country. In } \\
\text { the course of contracted land circulation, the sporadic experiments } \\
\text { did not form the achievements. And the government promoted the } \\
\text { circulation to be normal. The transaction of land indicator is also } \\
\text { dominated by the government. The price of land indicator is not the } \\
\text { real market price. After the land indicator landing, the huge income } \\
\text { of the urban construction land is the great impetus of the government } \\
\text { reform. Because of the excessive "offside" of the administrative } \\
\text { power, the market mechanism is difficult to develop. And the } \\
\text { peasants' rights and interests are not effectively protected. }\end{array}$ \\
\hline 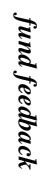 & $\begin{array}{l}\text { In addition to the normal state financial subsidies, Chengdu achieves } \\
\text { the rural back-feeding through farming funds, and village-level public } \\
\text { service financial funds. Other rural land income is also directly used } \\
\text { for the "agriculture, rural areas, and rural residents". }\end{array}$ & $\begin{array}{l}\text { The rural population in Chongqing is large and the financial burden } \\
\text { is heavy. It is very difficult to realize more financial funds to feed } \\
\text { back. Only through the "land indicator" transaction and other means } \\
\text { to transfer part of the urban construction funds improve the } \\
\text { production and living standards of the peasants. }\end{array}$ \\
\hline 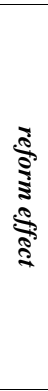 & $\begin{array}{l}\text { The per capita net income of rural residents in Chengdu was } 5642 \\
\text { yuan in } 2007 \text {. And the per capita disposable income of rural residents } \\
\text { in } 2016 \text { was } 18605 \text { yuan, more than tripling. The income gap between } \\
\text { urban and rural areas was reduced from } 2.63: 1 \text { to } 1.93: 1 \text {, far below } \\
\text { the national level. In the experiment of reform, Chengdu has } \\
\text { accumulated abundant practical achievements, especially the } \\
\text { certification right, which has been deeply recognized by the central } \\
\text { authorities. It is popularized in the whole country. And the pattern of } \\
\text { "agricultural co-operation system" has aroused extensive attention } \\
\text { from all circles of society. And it has explored many effective paths } \\
\text { for realizing "the separation of rural land ownership rights, contract } \\
\text { rights, and management rights". }\end{array}$ & $\begin{array}{l}\text { The per capita net income of rural residents in Chongqing was } 3509 \\
\text { yuan in 2007. And the per capita disposable income of rural } \\
\text { permanent residents in } 2016 \text { was } 11549 \text { yuan, nearly tripling. } \\
\text { However, it is still lower than the national level. The income gap } \\
\text { between urban and rural areas narrowed from } 3.91: 1 \text { to } 2.56: 1 \text {, } \\
\text { approaching the national level. The most important practice in } \\
\text { Chongqing is the "land indicator", which can only be popularized } \\
\text { and implemented in a few areas because of the restriction of the } \\
\text { current policy. }\end{array}$ \\
\hline
\end{tabular}




\section{REFORM OF RURAL LAND PROPERTY RIGHT SYSTEM IN CHENGDU AND CHONGQING: PROBLEMS AND STRATEGIES}

With the deepening of the reform, the deep-seated problems have become increasingly prominent. The contest between market and non-market rights from the relevant stakeholders has become increasingly intensified. And a series of sensitive issues, such as the restructuring of the distribution pattern of state, collective and individual interests, have been involved. And various contradictions have been escalated in the accumulation process.

\section{A. The Contradiction between the Guarantee of Peasants' Sustainable Development Right and the Imbalance of the System}

On the one hand, with the large-scale transfer of land, the rural surplus labor will gradually increase; the meagre rent income is difficult to maintain a livelihood. Many farmers only work in cities or in local enterprises to obtain wage income. However, the current economy of China enters the new normal state. The growth rate slows down. And the industrial structure urgently needs to have the adjustment. A large number of traditional industry enterprises close down one after another. And the urban employment pressure gradually climbs. Much surplus labor transfer will be the biggest difficult problem in the new period. At the same time, the government has not done a good job in the design of supporting policies. Many peasants can still rely on farming before land circulation to solve the problem of food and clothing. Once the land transferred out, they can idle at home. To certain extent, the farmers lost the land security, and gradually became the poor population. On the other hand, some farmers were forced to turn into citizens because of the expropriation of land. The farmers would get compensation. Due to the constraints of education level and skills, they are difficult to really integrate into the city life. And they lack sustainable livelihood security. For the current policy, it only considers the endowment insurance of landless farmers, and ignores the supply for long-term development of their knowledge and skills.

\section{B. The Contradiction between the Direction of Collective Construction Land Transfer and the Development Strategy of Urbanization}

Through the collation of collective construction land, this is the important basis of urbanization development. Most of them flow to the central city through the cross-regional index flow. The result is to further speed up the development of big cities and the surrounding urban areas, which runs counter to the national urbanization development strategy. It is not conducive to the development and construction of small towns. According to Wang Xiaoqin, vice president of the Chongqing Rural Land Exchange, more than $70 \%$ of the land indicators traded in Chongqing came from relatively backward areas such as northeast and southeast Chongqing. More than $95 \%$ of the land indicators were used in the main cities and surrounding areas, which undertook the functions of population and industrial agglomeration.

\section{The Contradiction between the Restraint of Property Right Hardening on the Development of Urbanization and "Returning Power and Empowerment"}

Through the certification, it strongly aroused the value of land in the hearts of farmers. Zhang Junlian (2014) cited the United States and Japan's most "nail" cases. We can't know that the clearer the property is, the smaller the transaction costs. [21] Luo Biliang (2014) found that the endowment effect of farmers on land is closely related to the intensity of property rights. [22] He Xuefeng (2013) explicitly proposed that farmers should be cautious about their land property rights. If the farmer's land property rights can be fully realized, rural non-agricultural land use is "in line with urbanization planning". It is precisely on the surface of urban development. It makes land far more valuable than agricultural land. The farmers can become overnight rich. They become huge land-earning class. And it is estimated to be no more than $5 \%$ of the total number of farmers. The other $95 \%$ can only "look forward to sighing". This kind of peasant's property right may damage the financial ability of the country. It makes the national finance more incapable of providing the strong transfer payment for the peasant of the whole country. And then, it would damage the interests of the overwhelming majority of the peasant of the whole country. [23] The National Development Research Institute of Peking University (2010) in the investigation of the reform of Chengdu agricultural land property right system found that some places do not make the certification arrangement for the land and housing in the urban planning area. In these areas where state land expropriation will take place in the future, once farmers are given the right to register and certify, it will increase the difficulty of the work. This also confirms the inherent contradictions and conflicts between the existing land expropriation system and the rights of farmers. [6]

\section{The Contradiction between the Original Intention of Reforming Design and of Reality}

The collective construction land in Jiaolong Industrial Port in Shuangliu County, "small property rights" housing as the representative of Pixian, and the collective construction land in Jinjiang District all contradict the current legal system. And they cannot provide legal evidence. And they have the huge risks. Along with the deepening of reform, the social stratum begins to divide again. The rural social relation begins to reconstruct in an all-round way. The game of interest group, government and peasant will be more and more inspired. The resistance and risk in front will be bigger and bigger. To balance the distribution of interest better is a difficult problem that must face. And then, it would further deepen the reform. In addition, it is not uncommon for peasants or village collectives to sell the right to use collective construction land privately to urban residents. In the long run, chaos and legal difficulties will inevitably become the shackles of the future reform. And the government should pay great attention to it. 


\section{E. The Contradiction between the Excessive "Offside" of Administrative Power and the Development of Rural Property Market}

In the transfer of collective construction land, the village committee or village group often exercises the collective ownership on behalf of the peasants, and the main position of the peasants as the collective members is alienated. At the same time, the excessive intervention of the government has been suppressing the development of the property right market. Because of the dispersed and weak position, the peasants are often at a bargaining disadvantage in the game of participating in the distribution of interests. It is difficult to be the executor of the independent property right and the main body of the market transaction. And naturally, they lose the fair position in the share of profits. In the reform of the "increasing and decreasing" or "land indicator" transactions, the margin of government rent earnings is enormous. The government would violate the peasants' willingness. Even if the peasants agree to reclamation, it is very difficult for the peasants to get the income they deserve after land consolidation. The village collective or higher government often seeks the rent from the land, and the anomie of power occurs. At the same time, the market seems to be the government's "doll" because the government controls the index pricing power.

\section{CONCLUSION}

In 2016, the Central Committee of the Communist Party of China (CPC) and the State Council successively issued the "Opinion on Improving the Method of Separating the Management Right of Rural Land Ownership" and the "Opinion on Steadily Promoting the Reform of Rural Collective Property Right System" which are programmatic documents for deepening the reform of rural land property right system in the new period. For the contractual management right, the key is to continuously explore the effective implementation method under the principle of "implementing collective ownership, stabilizing peasant households' contracting right, and releasing the land management right", So that the "three rights" can function well with a good result. To this, a lot of fruitful innovative modes have been accumulated all over the country The next step is to draw on past experience, learn from each other, promote in a systematic way and establish rules and regulations so that "separating three rights" can be promoted comprehensively. For collective ownership, our focus will be on activating three types of rural collective assets (resourcebased assets, operating assets, non-operating assets) giving farmers more property rights. , and building a property rights system and operation mechanism featuring clear boundaries and smooth operation. The focus of the reform is the reform of the joint-stock cooperative system of operating assets. The reform model of "two shares and one reform" of Songjiang in Shanghai and the reform model of "affirmative rights to households, indoor sharing, intranet circulation and permanent invariability" of Nanhai in Guangdong are the leading forces in the reform of collective property rights, which deserve to be studied and used for reference. In addition, farmers' active participation in land expropriation and their sharing of benefits from land added-value has become a univeral practice at the bottom. Exploring the reasonable proportion of peasants, land developers and governments at all levels in the distribution of land margin income and taking the way of land capitalization with peasants as the main body will be the focus of the reform of land expropriation system. [24]

Chengdu and Chongqing have made fruitful achievements and accumulated rich experience in the concrete practice of the reform of rural land property right system, which has produced positive demonstration and driving effect in the western region and even in the whole country. The Nineteenth National Congress of the Communist Party of China has upgraded the rural revitalization into one of the seven strategies of building a well-off society in an all-round way and building a socialist modern country in an all-round way. It would provide an important follow for the reform of rural land property rights in the new period. It is believed that with the deepening of the reform, the construction of new "agriculture, rural areas, and rural residents" with "strong agriculture, rich rural residents and beauty countryside" is imminent.

\section{REFERENCES}

[1] Chen Xiwen et al. 60 years of rural institutional changes in China [M] Beijing: People's Publishing House, 2009: 34-44. 陈锡文等.中国农 村制度变迁 60 年[M]. 北京: 人民出版社, 2009:34-44 页.

[2] Sun Chaoying et al. Reconstruction of rural property rights system in urban and rural coordination [M]. Chengdu: Southwestern University of Finance and Economics Press, 2015: 42-43. 孙超英等.城乡统筹中 的农村产权制度重构[M]. 成都: 西南财经大学出版社, 2015:4243 页

[3] Luo Biliang. Agricultural cooperative management: exploration and enlightenment of the new agricultural management system[J]. Social Sciences Scientist, 2015(5): 7-12. 罗必良. 农业共营制: 新型农业 经营体系的探索与启示 [J]. 社科科学家, 2015(5): 7-12 页.

[4] Research Group of Sichuan Provincial Academy of Social Sciences. Innovation of rural land property right circulation system in the construction of "test area" in Chengdu--A case study of "Two sharing and one reform" in Wenjiang District of Chengdu City $[\mathrm{J}]$. Rural Economy, 2009(9): 3- 7. 四川省社会科学院课题组. 成都 “试验 区”建设中的农村土地产权流转制度创新--以成都市温江区 “两 股一改”为例 [J]. 农村经济, 2009(9): 3-7 页.

[5] Yang Jirui et al. An innovative exploration of "land indicator" trading in Chongqing as an overall plan for urban and rural development[J]. Chinese Rural Economy, 2011(11): 4-22 杨继瑞等. 统筹城乡实践 的重庆 “地票” 交易创新探索 [J]. 中国农村经济, 2011(11): 4-22 页

[6] Yao Jinwei. Discussion on the common cooperative development model of land under the background of limited development zone--A case study of Wubao Town in Chongqing[J]. Chinese Rural Economy, 2014(7): 72-80. 姚金伟. 限制开发区背景下的土地共有合作开发 模式刍议--以重庆五宝镇为例 [J].中国农村经济, 2014(7): 72-80 页.

[7] Zhou Jian, Shi Guoqing. Three rural land transfer models for overall development in urban and rural areas and comparative research[J]. Rural Economy, 2011(8): 45-48. 周建,施国庆.城乡统筹发展的三种 农村土地流转模式及其比较研究 [J]. 农村经济, 2011(8): 45-48 页.

[8] Comprehensive Research Group of National Research Institute of Peking University. Returning rights and endowing land with rightsStudy on the exploration of Chengdu's land system reform $[\mathrm{J}]$. International Economic Review, 2010(2): 54-93. 北京大学国家发展 研究院综合课题组. 还权赋能一成都土地制度改革探索的调查研 究 [J]. 国际经济评论, 2010(2): 54-93 页. 
[9] Jiang Xiaoping. Returning rights and endowing land with rightsChengdu's Experience in Regulating Governance System Transformation [J]. Public Administration Review, 2011(6): 79-102. 姜晓萍. 还权赋能_治理制度转型的成都经验 [J]. 公共行政评论, 2011(6): 79-102 页.

[10] Sun Chaoying et al. Reconstruction of rural property rights system in urban and rural planning $[\mathrm{M}]$. Chengdu: Southwestern University of Finance and Economics Press, 2015. 孙超英等. 城乡统筹中的农村 产权制度重构 $[\mathrm{M}]$. 成都: 西南财经大学出版社, 2015.

[11] Yan Jinming. Evaluation on innovation model of land management system and policy choice of reform based on the coordinated development of urban and rural areas-A case study of Chengdu urban-rural comprehensive supporting reform test area[J]. China Soft Science, 2011(7): 1-8. 严金明. 基于城乡统筹发展的土地管理制度 改革创新模式评析与政策选择一以成都统筹城乡综合配套改革试 验区为例 [J]. 中国软科学, 2011(7): 1-8 页.

[12] Zhou Jingxiang, Lu Ming. The rural land transfer in the mainlandEnlightenment on the practice in Chongqing[J]. Journal of Public Management, 2011, 8(4): 85-95. 周靖祥,路铭. 内地农村土地流转何 去何从--重庆实践的启示 [J]. 公共管理学报, 2011,8(4): 85-95 页.

[13] Mei Zhe. Innovation of rural land system under the background of urban-rural integration - A survey of rural land system reform in Chongqing[J]. Central China Normal University (Humanities and Social Sciences), 2011, 50(3): 18-26. 梅哲. 城乡统筹背景下农村土 地制度创新--对重庆农村土地制度改革的调查研究 [J]. 华中师范 大学学报 (人文社科科学版), 2011,50(3): 18-26页.

[14] Yang Shunxiang. A comparative study of urban and rural integrated reform in Chengdu and Chongqing[J]. Western Conference, 2010,20(5): 8-19. 杨顺湘. 成都与重庆统筹城乡综合配套改革试验 比较研究[J]. 西部论坛, 2010,20(5): 8-19 页.

[15] China Land Resources News, http://www.gtzyb.com/yaowen/20120419_6442.shtml 中国国土资源 报 http://www.gtzyb.com/yaowen/20120419_6442.shtml

[16] Chengdu Business News, http://sc.cri.cn/549/2016/01/04/341s42970.htm 成都商报, http://sc.cri.cn/549/2016/01/04/341s42970.htm

[17] The data comes from the 2015 Chengdu Yearbook. 数据来自 2015 年成都年鉴。

[18] Xia Zhuxiang's speech at the 2016 Agricultural Work Conference in Chongqing. 夏祖相在重庆市 2016 年农业工作会上的讲话.

[19] Chongqing Land Indicator Reform: Let Farmers Realize Land Property Rights. http://www.ccle.cn/xwzx/xwdt/tdxw/html1747/10779.html 重庆地票改革: 让农民实现土地财产 权,http://www.ccle.cn/xwzx/xwdt/tdxw/html-1747/10779.html

[20] Chongqing's household registration system reform: 4.36 million people change from farmers to citizens, http://cq.qq.com/a/20160613/023146.htm 重庆户籍制度改革: 436 万人从农民变成市民,http://cq.qq.com/a/20160613/023146.htm

[21] Zhang Junlian. Application scope of coase property rights theory and development of land property rights theory [J]. Economic Research Guide, 2014 (31): 9-11. 张军连. 科斯产权理论的适用范围与土地 产权理论的发展 [J]. 经济研究导刊,2014(31):9-11 页。

[22] Luo Biliang. The market logic of farmland circulation-Analysis threads and case studies of "property rights intensity-Endowment effect-Trading devices"[J]. Southern Economy, 2014(5): 1-24. 罗必 良. 农地流转的市场逻辑一“产权强度-禀赋效应-交易装置”的 分析线索及案例研究[J]. 南方经济, 2014(5): 1-24 页.

[23] He Xuefeng. The logic of land rights II:-The truth and paradox of the reform of land rights [M]. Beijing: People's Oriental Press, 2013. 贺学峰. 地权的逻辑 II一地权变革的真相与谬论 [M]. 北京: 人民 东方出版社, 2013 .

[24] Zhang Shuguang. Bo Yi. Subdivision, Implementation and Protection of Land Rights[M]. Beijing: Social Sciences Academic Press, 2011. 张曙光. 博亦: 地权的细分、实施和保护 $[\mathrm{M}]$. 北京: 社会科学文 献出版社, 2011 